\title{
Uses and perceived benefits of children's recreational activities: the perspectives of parents and school professionals
}

\author{
Gaëlle Amerijckx ${ }^{*}$ and Perrine Humblet
}

*Correspondence:

gaelle.amerijckx@ulb.ac.be

CRISS-Centre de recherches

interdisciplinaire en

approches sociales de

la santé, Ecole de santé

publique, Université libre

de Bruxelles, 808 route de

lennik CP596, 1070 Brussels,

Belgium

\section{望 Springer}

\begin{abstract}
This paper examines recreational activities in children's free time, as a component of their wellbeing in a socio-ecological framework. Data comprise semi-structured interviews, conducted with 50 parents and 33 school professionals, within four contrasted areas of the Brussels-Capital Region — with regard to their economic affluence and availability of green areas. Families' perspectives and practices in terms of children's recreational activities are presented in relation to contextual (availability of parks and playgrounds; access to recreational services) and individual factors (families' socioeconomic and cultural profiles). They are then compared with the perspectives of school professionals. Concerning families, our results primarily show that all families reported using parks and playgrounds with their children. Besides, if many experienced some barriers to access recreational activities, their perspectives on the benefits of such services varied widely. Three main profiles of families, regarding their use and perception of recreational activities, were identified: users, involuntary non-users, and voluntary non-users. These perspectives were only partly similar to those of school professionals. Finally, recreational activities are discussed in relation to some major macro-level issues, such as social inequalities, accessibility to services, choice, as well as public policies in relation to children's free time.
\end{abstract}

Keywords: Recreational activities, Child, Parental choice, Free time, Qualitative research, School inequalities, Wellbeing, Public policies

\section{Background}

After-school programmes are largely documented in the United States, through the study of three main outcomes: academic achievement (Eccles and Templeton 2002; Cosden et al. 2004), "behavioural skills" (Mahatmya and Lomhan 2011; Rorie et al. 2011) and physical health, particularly the prevention of obesity (Elkins et al. 2004). Usually targeting children from low socioeconomic background and/or poor neighbourhoods, these programmes are assessed through their responsiveness to these main objectives.

In European countries, after-school programmes are progressively integrating education and care policies and studies considering this specific type of services are still scarce (European Commission et al. 2014). The northern countries were the first ones to develop recreational services, as we will call them from now on, around the 1960s-1970s (Zeiher 2011). They were immediately conceived as part of a fully integrated early

(C) 2015 Amerijckx and Humblet. This article is distributed under the terms of the Creative Commons Attribution 4.0 International License (http://creativecommons.org/licenses/by/4.0/), which permits unrestricted use, distribution, and reproduction in any medium, provided you give appropriate credit to the original author(s) and the source, provide a link to the Creative Commons license, and indicate if changes were made. 
childhood education and care (ECEC) system, which includes preschool, school and recreational services for school-aged children into a coherent, multifunctional and inclusive system (Kaga et al. 2010; Zeiher 2011). This universalist model of ECEC policy refers to the decommodification of social benefits (Esping-Andersen 1999), where every citizen is entitled to benefits, regardless of his/her contribution to the labour market. Elsewhere in Europe, the interest of public authorities in children's free time was more recent (around the mid-1990s) and rather motivated by economic, demographic, societal and spatial circumstances (Frønes 2011; Zeiher 2011).

On a societal level, the development of recreational services within ECEC policies takes part in the broader process of defamilisation (McLaughlin and Glendinning 1994) that has progressively externalised the care of children. Denmark, Finland, Norway and Sweden are clearly the first countries to have combined this externalisation of care of young children with the development of relevant public policies (Millar and Warman 1996; Leira 2002). Mothers' increased participation to the labour market created a need for childcare solutions outside of the home. From an exclusive responsibility of families, the care of young children has thus shifted towards a shared responsibility with public authorities that has led to the development of distinct ECEC policies in Europe, concerning childcare and preschool services (Leira 2002). Recreational services have followed thereafter and, in the Scandinavian welfare system where an expanding proportion of children are using recreational services, childhood is more and more becoming an "institutionalised" experience (Rasmussen 2004).

On a scientific level, institutional issues regarding children's free time revolve around four main aspects: (1) children's rights in reference to the Convention on the Rights of the Child (United Nations General Assembly 1989), with the issues of accessibility to services and infrastructures, or the freedom of choice and free disposition of one's own free time, and also to the right to play; (2) public health priorities (Dyment 2013; World Health Organization (WHO) 2014), and more precisely the obesity epidemic (WHO); (3) socio-educational challenges (Durlak et al. 2010; Guèvremont et al. 2014), such as school readiness, equity in school achievement, or language acquisition; and (4) public investments, through the setting of priorities. Where the first aspect, relating to children's rights, deals with the present child and his current wellbeing, the three other aspects refer to what Mollo-Bouvier (1994) and Strandell (2013) have associated with investments in human capital. These debates are paramount, since they significantly contribute to the case of recreational services as part of ECEC policies.

Children's free time can, however, not be limited to formal recreational activities. Various approaches to free time co-exist: from a residual perspective, of what is left after paid and unpaid labour (or school time) as well as personal care are subtracted (Goodin et al. 2005; Janssen and Rosu 2015), to an elective perspective, where the notions of choice (Vandewater et al. 2006) and leisure (Nippold et al. 2005) are central. Concerning children, recreational institutions can then either be included, excluded or be the focus of attention, depending on what aspects are in the definition. In a broad and inclusive perspective, children's free time covers a heterogeneity of situations that range from hobbies to sports, toys and games, outdoor play, reading, watching television, and hanging out (McHale et al. 2001). In a context of increasing development and use of recreational activities within children's free time, one could wonder what is still free in free 
time? Free play has shown its broad impact on young children's development, beyond physical health, on attention (cognitive development), affiliation (social development), and affect (emotional development) (Burdette and Whitaker 2005; Ginsburg et al. 2007). Moreover, children's emotional wellbeing is positively affected by their perception of an activity as play (Howard and McInnes 2012). When asked, children do describe recreational activities as activities that offer them more opportunities to choose their play, in comparison to home and to school playgrounds (King and Howard 2012). Issues related to free time are complex; more research is thus needed, from the standpoint of children, to assess the related benefits of recreational activities, as part of ECEC policies, within the panel of activities that children have access to in their free time.

Besides the choice and nature of activities, children's free time is also affected by spatial configurations. In urban contexts, children's free time is as much an issue of space as it is of time. High building density, combined with housing pressure on open spaces, and a higher density of traffic, leading to mobility issues (Oliver et al. 2011), have rendered access to safe and high-standard green spaces and public playgrounds (Allen et al. 2013) an acute challenge. Moreover, the rise of a risk-averse society (Gill 2006) has led to a withdrawal of children from the streets and, accordingly, some parents await for sustainable options regarding their children's free time. Besides the needed investments in green spaces and playgrounds in urban environments, comprehensive approaches to children's access to public space have flourished. UNICEF has, since 1996, advocated in favour of Child Friendly Cities as "places where children's rights to a healthy, caring, protective, educative, stimulating, non-discriminating, inclusive, culturally rich environment are addressed" (Riggio 2002). A perspective lobbying for a loose and open spatial organisation of cities is one that highlights the need for "children's places", which are physical and symbolic places assigned by children for themselves, instead of only "places for children" that are assigned by adults for children (Rasmussen 2004). In fully integrated ECEC systems, children are growingly framed by an institutional triangle of 'places for children'-the home arena, the school arena and the recreational facility-underestimating children's experience of restrictions and contradictions. In such circumstances, Rasmussen's plea leads to the need to investigate the potential effects of such institutionalisation on today's childhoods and the social space for 'children's places'.

With a focus on institutional issues relating to children's wellbeing, our aim in this paper is to look at children's recreational activities in terms of practices and perceived benefits. Our research rests upon a socio-ecological approach to wellbeing that heeds the intertwined and sometimes unequal nature of children's experiences with their physical and social living environments. The issue of recreational activities is thus located within the broader context of children's free time [in the line of McHale et al.s (2001) definition], and studied in relation to contextual (availability of parks and playgrounds; access to recreational services) and individual factors (families' socioeconomic and cultural profiles).

Belgium is characterised by an ECEC 'split system', where educational (i.e. preschool and compulsory school) and recreational services are under separate ministries and distinct regulations. Recreational activities here refer to activities regulated by specific childhood legislation and defined as (...) activities offered to children who are of age to go to preschool, to primary school or until they reach twelve years old, during their free time 
and with the exception of weekly periods that are covered by school. It includes independent supervised activities, as well as educational, cultural and sports activities (Ministère de la Communauté française 2003). The format of activities (such as the duration or the number of children enrolled per activity) may vary widely between activities (also according to the age group targeted) and providers (according to their resources): during school year, most activities last around $1 \mathrm{~h}$, and target groups of 7-20 children. The choice of activities for young children (under 6 years old) is however rather limited, due to a lack of diversity and supply (Aujean 2014). In the Brussels-Capital Region, about two-thirds of the services are non-profit organisations with activities outside the school premises, while the rest is run by local administrations and mostly takes place in schools (Delvaux and Vandekeere 2005). Furthermore, recreational activities are present in all types of socioeconomic areas in the Region, as a result of an important effort to coordinate them locally over the last 10 years. However, cooperation with schools and teachers is far from generalised, and the recreational sector still suffers from disrepute in terms of training, working conditions, wages, and specific pedagogic framework.

\section{Methodology}

Dataset

The data come from a research project portraying institutional issues regarding the wellbeing of urban children aged between 2 and 8 years. The study took place in the Brussels-Capital Region of Belgium, with $28.1 \%$ of its population of foreign nationality (ULB-IGEAT and OBSS 2010). The city is characterised by a steady increase in births over the past few years; a high proportion of migrants, who largely contribute to these births, with one in two of all newborns' mothers not being Belgian at the time of their child's birth (Leroy et al. 2013); and high socioeconomic inequalities among the population, i.e. housing conditions, employment, education and health (De Spiegelaere et al. 2009; OBSS 2014). In respect to these socio-demographic characteristics, the BrusselsCapital Region differs from the other two regions of Belgium (Flanders and Wallonia). As for policies and institutions of the Flemish Community and of the French-speaking Community concerning children, they overlap in Brussels. The region could be considered in that way as a kind of 'Belgian laboratory'. The families are free to use services from either Community. Although French and Dutch are the official languages of the region, with French as its most used language, roughly half of Brussels' inhabitants do not have either one as their mother tongue (Janssens 2013). French-speaking and Dutchspeaking schools enrol, respectively, 78.9 and $21.1 \%$ of pupils in preschools, and 82.3 and $17.6 \%$ of pupils in primary schools (IBSA 2012-2013).

In order to design a valid sample, a stratified purposive sample was selected. Firstly, four contrasted areas (regrouping several statistical sectors) were selected as survey areas, on the basis of three criteria (Table 1): the proportion of children within the population, as an inclusion criterion, since only areas with equal to or higher than average proportions of children were considered; and the average level of income of the population and the level of availability of green areas as our two segmentation criteria. The latter serves as an indicator of public investments on behalf of the population of children, since only areas with higher than average proportions of children (criterion 1) have been selected. Furthermore, green areas (and potential adjoining playgrounds) were 
Table 1 Criteria for the selection of survey areas

\begin{tabular}{llll}
\hline & Proportion of children & Level of income & Availability of green areas \\
\hline Area 1 & High & Low & Intermediate \\
Area 2 & High & Low & Low \\
Area 3 & Intermediate & Intermediate & High \\
Area 4 & Intermediate & High & High \\
\hline
\end{tabular}

Table 2 Description of samples procedures

\begin{tabular}{|c|c|c|c|c|c|}
\hline & \multicolumn{2}{|l|}{ Families } & \multicolumn{3}{|l|}{ Schools } \\
\hline & Solicitation procedures & Interviews & $\begin{array}{l}\text { Solicited } \\
\text { schools }\end{array}$ & $\begin{array}{l}\text { Participating } \\
\text { schools }\end{array}$ & $\begin{array}{l}\text { Individual } \\
\text { interviews }\end{array}$ \\
\hline Area 1 & 50 Post +2 consultations & $5+8$ & 6 & 4 & 19 \\
\hline Area 2 & 4 Consultations & 12 & 2 & 1 & 6 \\
\hline Area 3 & 100 Post & 13 & 3 & 2 & 7 \\
\hline Area 4 & 100 Post & 12 & 3 & 1 & 1 \\
\hline Total & 250 Post +6 consultations & 50 & 14 & 8 & 33 \\
\hline
\end{tabular}

considered as an extension of children's play areas, since they are children's favoured outdoor resource (Legendre 2011).

Secondly, within each area, two groups of proxy, or representatives for children were targeted for interviews: school professionals and parents. Indeed, both groups were considered for their specific expertise on children, as main responsible adults in children's two primary arenas: home and school.

Concerning the construction of our sample of parents, we had one criterion of inclusion: families comprising at least one child aged between 2 and 8 years were considered. The selection of families was based on two complementary procedures: parents were randomly selected on the basis of a population list (meeting our inclusion criteria: age of the child and survey area) and contacted by post, or they were solicited while attending a children's public preventive care centre. All in all, each willing parent was interviewed, whether or not from foreign nationality ${ }^{1}$. Recruiting procedures were stopped in each area when saturation was met (Table 2).

As for school professionals, all French-speaking schools in each survey area (inclusion criteria) were solicited by post, to announce our research and request, and then by phone, to seek response to our request and, where appropriate, organise our coming. Upon principals' authorisation, professionals working with children aged between 2 and 8 years were more specifically solicited (inclusion criterion) and all agreeing parties (teachers, teachers' assistants, a principal, and a secretary) were interviewed. Our segmentation criteria referred to the types of schools (not discussed here) and grade levels (from first year of preschool to second year of primary school) included. The target sample was not met in area 4, due to a lack of availability of school professionals or their unwillingness to participate to our research (Table 2). In the one school of that area

\footnotetext{
${ }^{1}$ Our areas reflect this trend, with variations amounting to: $25 \%$ in area 1 (Moroccans being first); about $30 \%$ in area 2 (with Turkey and North Africa as firsts); $14 \%$ in area 3; and $27 \%$ (with three quarters originating from Europeans countries) in area 4 . For more detailed information on our sample, see Table 3.
} 
Table 3 Socio-demographic characteristics of families

\begin{tabular}{|c|c|c|c|c|c|c|c|c|c|c|}
\hline & \multicolumn{2}{|c|}{$\begin{array}{l}\text { Household } \\
\text { type }\end{array}$} & \multicolumn{3}{|c|}{$\begin{array}{l}\text { Number of children } \\
\text { in household }\end{array}$} & \multicolumn{2}{|c|}{ Parents' age range $(n)$} & \multirow[t]{2}{*}{$\begin{array}{l}\text { Mothers' nation- } \\
\text { ality at birth }\end{array}$} & \multicolumn{2}{|c|}{$\begin{array}{l}\text { Parents' activity status } \\
\text { in household }\end{array}$} \\
\hline & Single & Couple & One & Two & $\begin{array}{l}\text { Three } \\
\text { or more }\end{array}$ & Mother & Father & & Mother & Father \\
\hline $\begin{array}{c}\text { Area } \\
1\end{array}$ & 4 & 9 & 4 & 5 & 4 & $25-40(13)$ & $34-49(9)$ & $\begin{array}{l}8 \mathrm{MA}, 2 \mathrm{BE}, 1 \mathrm{Bl}, 1 \\
\quad \mathrm{Cl}, 1 \mathrm{DE}\end{array}$ & $\begin{array}{l}8 \text { Inactive; } 2 \\
\text { unem- } \\
\text { ployed; } 3 \\
\text { employed }\end{array}$ & $\begin{array}{l}1 \text { Unem- } \\
\text { ployed; } 8 \\
\text { employed }\end{array}$ \\
\hline $\begin{array}{c}\text { Area } \\
2\end{array}$ & 4 & 8 & 2 & 5 & 5 & $25-47(12)$ & $27-47(8)$ & $\begin{array}{c}4 \mathrm{MA}, 3 \mathrm{BE}, 1 \mathrm{AO} \\
1 \mathrm{CM}, 1 \mathrm{GH}, 1 \\
\mathrm{SL}, 1 \mathrm{SN}\end{array}$ & $\begin{array}{l}5 \text { Inactive; } 4 \\
\text { unem- } \\
\text { ployed; } 3 \\
\text { employed }\end{array}$ & $\begin{array}{l}2 \text { Unem- } \\
\text { ployed; } 6 \\
\text { employed }\end{array}$ \\
\hline $\begin{array}{c}\text { Area } \\
3\end{array}$ & 2 & 11 & 1 & 7 & 5 & $30-45(13)$ & $37-52(11)$ & $\begin{array}{c}6 \mathrm{BE}, 2 \mathrm{DZ}, 1 \mathrm{AL}, 1 \\
\mathrm{CG}, 1 \mathrm{MA}, 1 \mathrm{PT}\end{array}$ & $\begin{array}{l}2 \text { Inactive; } 2 \\
\text { unem- } \\
\text { ployed; } 9 \\
\text { employed }\end{array}$ & $\begin{array}{l}1 \text { Inactive; } 2 \\
\text { unem- } \\
\text { ployed; } 8 \\
\text { employed }\end{array}$ \\
\hline $\begin{array}{c}\text { Area } \\
4\end{array}$ & 0 & 12 & 3 & 5 & 4 & $34-49(12)$ & $34-58(12)$ & $8 \mathrm{BE} ; 3 \mathrm{FR} ; 1 \mathrm{DE}$ & $\begin{array}{l}4 \text { Inactive; } 8 \\
\text { employed }\end{array}$ & 12 Employed \\
\hline Total & 10 & 40 & 10 & 22 & 18 & $25-49(50)$ & $27-58(40)$ & $\begin{array}{l}19 \mathrm{BE}, 13 \mathrm{MA}, 3 \\
\mathrm{FR}, 2 \mathrm{DE}, 2 \mathrm{DZ} \\
1 \mathrm{PT}, 1 \mathrm{AL}, 1 \mathrm{BI} \\
1 \mathrm{CG}, 1 \mathrm{Cl}, 1 \mathrm{AO}, \\
1 \mathrm{CM}, 1 \mathrm{GH}, 1 \\
\mathrm{SL}, 1 \mathrm{SN}\end{array}$ & $\begin{array}{l}19 \text { Inactive; } 8 \\
\text { unem- } \\
\text { ployed; } 23 \\
\text { employed }\end{array}$ & $\begin{array}{l}5 \text { Unem- } \\
\text { ployed; } 1 \\
\text { inactive; } 34 \\
\text { employed }\end{array}$ \\
\hline
\end{tabular}

AL Albania, AO Angola, BE Belgium, BI Burundi, CG Congo, Cl lvory Cost, CM Cameroun, DE Germany, DZ Algeria, FR France, GH Ghana, MA Morocco, PT Portugal, SL Sierra Leone, SN Senegal

that had agreed to participate, we stopped after two reminders (phone contacts with the principal) since they did not provide any further reaction from the staff or any conclusive idea of incentive towards them. The principal of that school was thus our only professional's interview in that area.

Semi-structured individual interviews ${ }^{2}$ were carried out in French $^{3}$ in both groups. Topics discussed with the parents included: the household's composition, its financial situation and housing; the neighbourhood's rating; the family's social networks and free time activities-including recreational activities; as well as the child's health and care (education) pathways, and general wellbeing. With professionals, we covered: the classroom and school environments (in their physical and social aspects); relationships with parents and the neighbourhood; children's recreational activities and general wellbeing.

Anonymity was ensured and, with participants' agreement, interviews were recorded and transcribed. For the six parents who refused recording, extended reports of the interviews were subsequently drafted. All interviews were conducted between May 2010 and October 2011. For a brief presentation of socio-demographic characteristics of both groups of respondents, see Tables 3 and 4 . As for the 50 children for whom data were collected within families, we find an equal share of boys and girls with a mean age of: 4.4 in area 1; 4.1 in area 2; 6.0 in area 3; 5.3 in area 4 . All children attended preschool at

\footnotetext{
2 "Semistructured interviewing is an overarching term used to describe a range of different forms of interviewing most commonly associated with qualitative research. The defining characteristic of semistructured interviews is that they have a flexible and fluid structure, unlike structured interviews, which contain a structured sequence of questions to be asked in the same way of all interviewees. The structure of a semistructured interview is usually organized around an aide memoire or interview guide. This contains topics, themes, or areas to be covered during the course of the interview, rather than a sequenced script of standardized questions. The aim is usually to ensure flexibility in how and in what sequence questions are asked, and in whether and how particular areas might be followed up and developed with different interviewees" (Mason 2004).

3 With the exception of one interview where we had to switch to English since the communication was rendered too difficult on both ends.
} 
Table 4 Socio-demographic characteristics of school professionals

\begin{tabular}{|c|c|c|c|c|c|c|c|c|c|}
\hline & \multirow[t]{2}{*}{ Sex } & \multirow[t]{2}{*}{ Age } & \multirow{2}{*}{$\begin{array}{l}\text { Years of } \\
\text { experience }\end{array}$} & \multicolumn{6}{|c|}{ Teaching grades/position } \\
\hline & & & & Mo-1 & M1-2 & M2-3 & P1 & P2 & Other \\
\hline Area 1 & $19 \mathrm{~F}$ & $23-50$ & $1-30$ & 3 & 1 & 5 & 4 & 3 & $\begin{array}{l}\text { P4 } \\
\text { Secretary } \\
\text { Trainer (M0-P6) }\end{array}$ \\
\hline Area 2 & $6 \mathrm{~F}$ & $27-48$ & $5-27$ & 2 & 2 & 1 & 0 & 1 & / \\
\hline Area 3 & $6 \mathrm{~F}, 1 \mathrm{M}$ & $31-49$ & $1-27$ & 3 & 0 & 2 & 0 & 0 & $\begin{array}{l}\text { Principal } \\
\text { Secretary }\end{array}$ \\
\hline Area 4 & $1 \mathrm{M}$ & 39 & $4(10)$ & 0 & 0 & 0 & 0 & 0 & Principal \\
\hline Total & $31 \mathrm{~F}, 2 \mathrm{M}$ & $23-50$ & $1-30$ & 8 & 3 & 8 & 4 & 4 & 6 Others \\
\hline
\end{tabular}

some point, which is consistent with local enrolment rates of $96.9 \%$ of two and a half to 5-years-old children enrolled in 2007-2008 in Brussels (Humblet 2011).

\section{Scope and data analysis}

Through an inductive approach of our data, we performed a content analysis of our interviews that included: a free floating reading of all transcripts; an inductive identification process of categories related to wellbeing; and therein the identification and labelling of categories that corresponded to institutional issues; the embedding of the analysis of these issues in our socio-ecological framework. Through that process, recreational activities, as part of the broader issue of free time emerged as a main topic of interest for parents; where they showed much care for their children's free time, the issue of recreational activities crystallised the tensions between individual strategies and perspectives and contextual factors - as expressed by families. Their practices on the one hand, and their discourses as well as those of school professionals on the other hand, are confronted here.

\section{Results}

The analysis of parents' practices of and discourses on recreational activities, as part of children's wellbeing in their free time, permitted us to identify a generalised used among them of parks and playgrounds, and three broad profiles of positioning about utilisation of recreational services. Based on demand and accessibility issues, as expressed by parents, these three profiles are labelled as: users, voluntary non-users and involuntary non-users of recreational activities. As for the analysis of professionals' perspectives on recreational activities, it lead to the identification of one main type of discourse, the school discourse, which is presented at last and confronted to parents' perspectives.

The results hereunder thus contain two broad sections: families' patterns of use and discourses on the one hand, and school professionals' discourses on the other hand.

\section{Families perspectives}

\section{Some convergences among families}

All in all, every family addressed the issue of physical activity, as part of children's wellbeing, through recreational activities and/or family activities. All 50 families reported going to parks and playgrounds with their children, but they did it according to very 
different patterns. In socio-economically disadvantaged neighbourhoods, characterised by small housing, larger families and households with limited resources, green spaces and public playgrounds were reported to be visited every other day in area 1 (high availability) and more likely only over the weekend in area 2 (low availability), where families had to go further away. The availability of public transportation and/or cycling tracks was mentioned as being decisive when it comes to getting to these parks and green spaces.

'So we take the bike, we go up there since there are cycling tracks. They're safe so we can go up to the playground by bike. And they can ride.' (Mother, two children, area 3)

Recreational activities were also widely reported by parents as in favour of their children's wellbeing. But before going into it in details, let us mention some restrictions encountered by most families: (a) high fees, especially for the summer period; (b) overspecialisation of services, regarding age groups or type of activities, since families with more than one child have to juggle with several services at the same time; (c) unsupported daily trips between school and services, during office hours; (d) uneven distribution of supply, since certain activities cannot be found within a reasonable distance; (e) and poor access to information regarding available activities and the appropriate time to book them were mentioned as problems in our interviews. These barriers were mostly reported as limitations of use rather than actual barriers to access. Indeed, the fundamental difference that we observed between families referred to their perspective on the benefits of recreational activities for children's wellbeing, even if for some families that were deprived of access to recreational activities for their children, affordability was the key issue.

\section{Some main divergences among families}

Now, as we will show, families can be distinguished into three main profiles, regarding the combination of their uses of and perspective on recreational activities: users, involuntary non-users, and voluntary non-users. These profiles take into account parents' motivations to use or not to use recreational activities in relation to their children's wellbeing, and so they reflect distinct educational models, financial circumstances and levels of availability of parents to take care of their children during their free time. We will review these main aspects raised by parents in order to refine these three profiles.

\section{Users, a diverse community}

About half of children (23 out of 50) were reported as participating in recreational activities, from one to five times per week. Thus what could wrongly appear, in this following section, as distinct types of recourse to recreational activities depending on the discussed activity (sports, arts, outdoor activities, etc.) may well in fact depict various ways in which certain families see the many potential benefits of recreational activities for their children.

Many parents emphasised the need for fun and leisure time in recreational activities so that it offers children experiences outside the activities and goals of school. This perspective on children's needs, centred on the pleasure and contents of activities chosen 
by children, was a common denominator among them. And so was the need to be physically active. Sport was indeed the most cited recreational activity, since it concerned 21 out of the 23 children enrolled in one. Psychomotor activities were widely reported among younger children (preschoolers), individual sports (gymnastics, tennis, swimming, martial arts, etc.) across all ages, as were team sports (basketball and football) but more marginally.

'Sport is good for the development of the body.' (Mother, four children, area 1)

About ten parents insisted on the need for activities that go beyond a simple attendance, to offer opportunities for children to discover and learn about the world. Recreational services were thus identified as a gateway onto the world, besides children's two main living environments (home and school). More so, five parents explicitly emphasised the learning process involved in activities: some were referring to specific contents that were not necessarily available at school or home (with 'school-like' activities as second most popular type of recreational activities, learning another language was extremely popular); others referred to the transmission of values, such as 'effort' and 'perseverance,' with an activity that lasted over time.

Music is a fun thing. It needs some getting used to and some practice. We must also learn that if we do something regularly and with some effort, it'll be fun afterwards. At first and then from time to time, it's hard. But if we continue, it's to get the experience. (Mother, three children, area 4)

The opportunity to socialise with peers was also largely stressed as a gain from participating in recreational activities. Although all children in our sample were attending school or preschool, and were thus already in contact with peers, many parents looked at recreational activities as a distinct opportunity to interact with other children. These services were then seen as a social environment, distinct from home and from school. Children would be confronted with other rules and other people, and would then learn more about respect and living together.

I like it a lot. It opens their mind, they discover other things, they're under an authority that is not ours. (...) They must follow the rules, that means hold hands, behave normally in society.' (Father, two children, area 2)

For other families, participation achieves social reproduction. Youth movements were specifically reported as all three parents whose children were enlisted in such organisations specified that it was because they, as parents, had participated when they were young. Families with high cultural and economic capital selected activities for their own children by activating their social networks (friends and parents from school mostly).

It is arranged between the parents: 'Who wants to do soccer?' There are five boys now who do soccer, so we can manage. It's great. Hockey, he does it with his friends, horse riding with his friends, flute too. There are always friends. It's good. (Mother, three children, area 4)

Five other families had registered their children to Arab or Islamic classes. In such cases, the cultural (religious or linguistic) transmission was explicit. 
'Us, parents, we have been to the Islamic school, we know what religion is. Because there are some who are Muslims like that, but who don't know anything. But I want my children to know it.' (Mother, four children, area 1)

\section{Involuntary non-users, or when choice is not the issue}

We encountered about a dozen families for whom choice of recreational activities was not the issue. These families were suffering from social isolation and precariousness or even poverty, either brought on by a change in the household situation (single mothers), employment termination (by both parents), or a child's poor health (an undiagnosed frailty or a late discovery of deafness), but always by a more general profile of immigrant families with a low educational background. Among these families, single mothers appeared estranged from their own neighbourhood, standing out as single parents in an environment where dual households are the most common social unit.

In such contexts, recreational activities were often depicted as part of an unknown territory. Some families had never even heard of such services, although many showed interest in them. Other parents expressed their hopelessness to be able to offer such activities to their children due to lack of money, time, or resources to anticipate and react to unexpected events.

Yes, sure, activities for children... Me, I don't know where, I don't know... [Why would you want that?] To play... I don't know. Because, me, I have the children, no activities, I didn't know [experience] activities, me... Yes... It would be nice; it's best, activities for children (Single Mother, two children, area 1)

Recreational activities were seen in this group, like school, as places for new opportunities for children; opportunities that they, as parents, could not provide.

\section{Voluntary non-users, when family is the absolute priority}

Lastly and more surprisingly, some 15 interviewed families did not consider recreational activities as beneficial to their children's wellbeing. The economic function of recreational activities was invoked as a main explanation for not using the services. Indeed, without trying to downgrade or argue against their quality, these parents perceived recreational services as solely designed for children whose parents were both working and who had thus limited availability to take care of them. As it was, we were facing here two-parent families, with at least one economically inactive parent-neither employed nor unemployed-(in all but one case the mother was inactive), and who were all (first or second generation) migrants.

'No... [You're not interested by these services?] No... but I'm here. I prefer when we are together when there's no school. It's important to be with the family. (Mother, three children, area 2)

These parents deeply stressed their wish to spend as much time as possible with their children, to enjoy plenty of quality-time as a family. Those moments were depicted as full days spent over the weekend at the park (i.e. wider open spaces, situated outside of their neighbourhood and comprising parks, playgrounds and other facilities for families 
with small children), or with the extended family or very close friends. There appeared to be a certain idea of tradition and positive routine for the whole family.

\section{What sorts of divergences?}

Without trying to draw hasty conclusions, lets us note that the two families with the same socio-demographic pattern as voluntary non-user families whose children did use recreational activities were families where the mother, though immigrant, had been fully educated in Belgium - as opposed to a later arrival in the country as a child or adolescent with their parents. One could hypothesise that the full experience of the Belgian education system, by either one of the parents themselves (or maybe just the mothers, as in our case), may have reduced, to some extent, the unfamiliarity gap with the local educational services-which would, in this case, include recreational activities.

Having fun and leisure time, discovering and learning about the world, socialising and ensuring cultural and social reproduction are the main features that help us see how families' characteristics and context can come together to define different educational patterns regarding children's free time.

\section{Into the school discourse}

Perspectives on recreational activities of users' families were close to those of school professionals.

According to professionals, recreational activities expose children to otherness through a diversity of experiences, outside the familiarity of home and school environments, which help them grow and eventually gain empowerment. Focus was either set on new activities (whether sports, arts, culture, or others), new people (essentially peer relationships), new territories (mainly outside of a highly deprived neighbourhood), new mentalities (regarding rules, for instance), or on new aspects of children's developing personality-in terms of their potential.

Interestingly, they made parallel comments about school trips, whether these covered general activities (sports, culture or arts) or specific interactions with the natural environment. School professionals perceived, to various degrees, that one of their missions was to open up children to possibilities that the world has to offer and the need to behave respectfully towards it. In this manner, professionals aimed to render children full citizens-with rights and obligations.

Museums are fundamental! Just as to go see people who tell tales, with puppets, with any support... actually anything that is artistic and that allows therefore a greater tolerance because of a better understanding of the world. (Female teacher, 15 years of experience)

Behind the idea of widening children's perspectives, some professionals specifically mentioned the inability of the educational system to stem the production of inequalities. With that in mind, more than one emphasised the added value of recreational activities, especially for disadvantaged children and children with learning disabilities, as well as for children living in a foreign monolingual home environment. Recreational activities were then seen as additional educational environments. In this perspective, the 
institutional triangle is acknowledged: home, school and recreational activities all form places for educational experiences.

Conversely, other professionals depicted the extreme tiredness of certain children who were over-exposed to recreational activities. As was previously mentioned, children in our sample were reported to participate in up to five activities per week. So these professionals pleaded for a more comprehensive approach to children's time, one that acknowledges the time spent at school and the energy that it requires.

Even the ones in M3 are tired at three thirty... It's long! (So what's the best?) Ideally, to go home, to rest, to take the time to have a snack, and then, after, to do something, if one feels like it. But not necessarily every day, and not with this rhythm. (Female teacher, 10 years of experience)

Professionals also brought up children's need for idleness. Such time was conceived as a time away from productivity and organised activities (i.e. recreational activities), a time for freedom and boredom. This perspective thus advocates for free time as a time and place designed by children.

Playing with friends, it's learning! To play freely, I mean. Without setting any challenge, without imagining for them. (...) I think it is as enriching and important for the general wellbeing, as to always keep them busy, without letting them imagine, create, structure their learning. (Female teacher, 20 years of experience)

\section{Discussion}

The point of view of parents and school professionals: so what?

In this paper, we have studied recreational activities in relation to children's wellbeing. Parents and school professionals that we interviewed had distinct perspectives.

Parents expressed a variety of perspectives on the potential benefits of recreational activities for their children's wellbeing. Three profiles, economically and socio-culturally driven, were drawn out: voluntary non-users, involuntary non-users and users of recreational activities. Where issues of social isolation and economic deprivation explained much of the pattern of involuntary non-users, family educational patterns distinguished the voluntary non-users from the users. Indeed voluntary non-users expressed their choice not to enrol their children in recreational activities, while users did the opposite. However, where choice would seem to be a core aspect here, one could ask to what extent we can speak of actual choice. Indeed, differences in family resources, in reference to social and cultural capitals (Bourdieu 1979), combined with differences of access to recreational services due to contextual factors (mainly linked to the supply structure and the costs of services), affect families' capacities to understand the nature of the offer of recreational services, as part of ECEC policies, and thereafter to make real choices for their children. Indeed, all parents showed interest for school and its paramount role in defining their children's future. But coming back to recreational activities, it seemed we had on the one hand families reproducing habits of using recreational services, and on the other hand families reproducing the habit of not using them. However, the fact that involuntary non-users and users acknowledged the three components of the institutional triangle (Rasmussen 2004) - home, school and recreational services-as part of 
children's wellbeing, while voluntary non-user families did not (only home and school were identified), leads us to nuance this perspective. Indeed, the profile of involuntary non-users corresponds to parents most of whom have not experienced these local recreational activities themselves. Yet they perceive these activities as opportunities, which they cannot provide themselves, for their children (Kaat et al. 2011). Individual and contextual factors do appear to produce various perspectives and practices among families concerning recreational activities for their children.

Among school professionals, recreational activities were repeatedly identified as opportunities to develop social and educational skills. Children from migrant low socioeconomic backgrounds were more specifically targeted, through the benefits of language acquisition and the prevention of school difficulties. We should emphasise that these educational benefits were likely this widely mentioned in our interviews since most professionals were working in neighbourhoods of low socioeconomic status. Nevertheless, the temptation would be great to label recreational services as part of a toolset to counter school inequalities, especially since the educational system in Belgium is known to increase social inequalities (PISA 2012), and preschool participation being less frequent among migrant families (European commission et al. 2014).

In principle, recreational services under French-speaking authorities aim to contribute to the development and wellbeing of children, as well as to social inclusion. They do not, as such, target educational benefits. When confronting parents' perspectives on the institutional discourse-as of school professionals we interviewed-about the benefits of recreational activities for children's wellbeing, we see the proximity between user families and school professionals on the one hand, and the distance between voluntary nonuser families and school professionals on the other hand. In other words, where users and professionals acknowledge the institutional triangle, voluntary non-users do not. Moreover, it appears that the children who would benefit the most from recreational activities, according to professionals, would be the least likely to resort to these when considering families' profiles.

\section{Policy issues}

On a macro-level, this proximity of discourses between school professionals and families using recreational services leads to the question of the underlying values of accessibility of the recreational sector. In other words, it is unclear if the policy on recreational services follows a universalist model, based on the inclusion of all who desire to use such services, or if it follows a universalising model, based on a dominant and homogeneous model of "good childhood" that would now also concern how children spend their free time. The diversity of factors explaining the (non)-recourse to recreational activities requires a policy that addresses the complex challenges of accessibility, one that would require the acknowledgement of the diversity of families and therefore of their needs (Vander Gucht 1995). So far, the recourse to these services is considered as an opportunity that is at the discretion of families and that is used on voluntary basis.

A clarification on the status and the objectives of this developing policy is also needed to avoid the limitations of 'established truths' (Strandell 2013) that mask normalising discourses, such as the one of a "good childhood". In this line, the political argument should be distinguished from the scientific one; too much emphasis is nowadays devoted 
to economic efficiency in political debates regarding ECEC policies, clearing out all possibilities of various policy orientations (Morabito et al. 2013).

If research on recreational activities has mainly focused on educational benefits and has shown certain positive results on at-risk populations (Durlak et al. 2010), we do not know if the use of such services would have any impact on school inequalities in Belgium, and therefore on school achievement. Research is still needed, especially in a context where a growing discourse on their perceived educational benefits is observed and could lead to a broader promotion of their use.

Furthermore, one could wonder how a policy towards systematic or broad enrolment in recreational activities would affect children's free time. Far from denying the actual recreational potential of these services, the access of children to non-institutionalised free time would be compromised. Yet, as was mentioned in our results, parents and professionals do consider children's access to an actual free time as paramount for their wellbeing. Research has also shown that children conceive free time as time away from adult supervision (Mayall 2000). Children's right to free time is increasingly pressured by a reduced autonomy in their play (Veith et al. 2006) and by an increasingly utilitarian approach towards their free time (Mollo-Bouvier 1994), which renders idleness an increasingly difficult activity for them to justify to adults (Griffiths 2011). This issue surely needs further investigations.

At last, let us emphasise that the development and sustainability of public policies regarding recreational activities in highly dense and heterogeneous urban environments relies on the interconnectedness of distinct policies-such as spatial planning, mobility, or education (Hood 2007), in order to meet an increasingly diverse demand: from full defamilisation (McLaughlin and Glendinning 1994), which calls for a broad supply of recreational services, to full refamilisation of free time, which relies on other public investments to support families with children in their free time. Indeed, as we have shown it, the availability of parks and playgrounds is part of this equation of children's free time in the Brussels-Capital Region. The literature shows that children themselves consider these outdoor spaces to be important spaces for play (Griffiths 2011), although they do not use them all in the same ways (Legendre 2011) - as was the case in our study. There is an overriding need for proximity, quality and diversity in the supply of these infrastructures: mixed-spaces for families with several children (Veith et al. 2006), as well as for children to exercise their creativity (Fjørtoft 2004). At the level of cities, neighbourhood greenness has proven to encourage children to go out and be physically active (Grisby-Toussaint et al. 2011). But safety has been repeatedly reported as parents' main concern regarding their children's outdoor activities (Gill 2006; Veith et al. 2006; Carver et al. 2008). Children themselves complain about their unequal access to public space, as well as to leisure and play infrastructures in urban environments (Hood 2007). Cross-sectoral policies are thus needed: social cohesion, accessibility to structures, and traffic safety have all been identified as paramount (Aarts et al. 2011).

\section{Conclusion}

Individual and contextual factors do appear to produce various perspectives and practices among families concerning the use of recreational services for their children. Parks and playgrounds on the other hand are used by all families. Nevertheless, the 
potentially socially driven nature of the use of such services begs for more research. The acknowledgment of a diversity of perspectives on the added value of recreational activities, as elective activities, to children's wellbeing leads to the recognition of a diversity of practices and of needs. In this perspective, affordability in children's free time can be addressed, policy-wise, through two main channels: the provision of high-quality, diverse and accessible recreational services, in the line of a universalist model; and an parallel offer of parks and playgrounds in combination with an improved access to public space at large for children. In so doing, children's access to free time would be ensured and the need for children's places would be in balance with the need for places for children (Rasmussen 2004).

Authors' contributions

GA conceived and carried out the study; performed the analyses and drafted the manuscript. PH participated in the design of the study; supervised the analysis process and helped draft the manuscript. Both authors read and approved the final manuscript.

\section{Acknowledgements}

This work was supported by the Institut bruxellois pour la recherche et l'innovation (Innovlris), in Belgium [PRFB 2011-126] as well as by the Fonds David et Alice Van Buuren.

\section{Compliance with ethical guidelines}

\section{Competing interests}

The authors declare that they have no competing interests.

Received: 28 January 2015 Accepted: 24 August 2015

Published online: 25 September 2015

\section{References}

Aarts, M. J., Schuit, A. J., Van de Goor, I. A. M., \&Van Oers, H. A. M. (2011). Feasibility of multi-sector policy measures that create activity-friendly environments for children: results of a Delphi study. Implementation Science,. doi:10.1186/1748-5908-6-128.

Allen, E. M., Hill, A. L., Tranter, E., \& Sheehan, K. M. (2013). Playground safety and quality in Chicago. Pediatrics, 131(2), $233-241$.

Aujean, S. (2014). Les grands enjeux de l'accueil temps libre à Bruxelles: synthèse des analyses des besoins. Grandir à Bruxelles, 29, 17-21.

Bourdieu, P. (1979). La distinction. Critique sociale du jugement. Paris: Editions de Minuit.

Burdette, H. L., \&Whitaker, R. C. (2005). Resurrecting free play in young children. Archives of Pediatrics Adolescent Medicine, 159(1), 46-50.

Carver, A., Timperio, A., \& Crawford, D. (2008). Playing it safe: the influence of neighbourhood safety on children's physical activity-a review. Health and Place, 14(2), 217-227.

Cosden, M., Morrison, G., Gutierrez, L., \& Brown, M. (2004). The effects of homework programs and after-school activities on school success. Theory into Practice, 43(3), 220-226.

De Spiegelaere, M., Closon, M.-C., Deboosere, P., Humblet, P. (2009). Citizens' forum of Brussels. Health and quality of life in Brussels. Brussels Studies Synopsis, Vol. 11, pp. 1-11. http://www.brusselsstudies.be/medias/publications/EN_81_ CFB11.pdf. Accessed 20 May 2015.

Delvaux, D., Vandekeere, M. (2005). L'accueil des enfants en dehors des heures scolaires en 2002: Etat des lieux et analyse des besoins. Bruxelles: Observatoire l'enfant, de la jeunesse et de l'aide à la jeunesse. http://www.oejaj.cfwb.be.

Durlak, J. A., Weissberg, R. P., \& Pachan, M. (2010). A meta-analysis of after-school programs that seek to promote personal and social skills in children and adolescents. American Journal of Community Psychology, 45(3-4), 294-309.

Dyment, J. (2013). Factors that limit and enable preschool-aged children's physical activity on child care centre playgrounds. Journal of Early Childhood Research, 11(3), 203-221.

Eccles, J. C., \& Templeton, J. (2002). Extracurricular and other after-school activities for youth. Review of Research in Education, 26(1), 113-180.

Elkins, W. L., Cohen, D. A., Koralewicz, L. M., \& Taylor, S. N. (2004). After school activities, overweight, and obesity among inner city youth. Journal of Adolescence, 27(2), 181-189.

Esping-Andersen, G. (1999). Social foundations of postindustrial economies. Oxford: University Press.

European Commission, EACEA, Eurydice, Eurostat. (2014). Key data on early childhood education and care in Europe. 2014 edition. Luxembourg: Publications Office of the European Union. http://eacea.ec.europa.eu/education/eurydice/ documents/key_data_series/166EN.pdf. Accessed 20 May 2015. 
Fjørtoft, I. (2004). Landscape as playscape: the effects of natural environments on children's play and motor development. Children, Youth and Environments, 14(2), 21-44. http://www.colorado.edu/journals/cye/14_2/article2.htm. Accessed 20 May 2015.

Frønes, I. (2011). Childhood: leisure, culture and peers. In J. Qvortrup, W. A. Corsaro, \& M.-S. Honig (Eds.), The Palgrave handbook of childhood studies (pp. 273-286). Basingstoke: Palgrave Macmillan.

Gill, T. (2006). No fear. growing up in a risk averse society. London: Calouste Gulbekian Foundation. http://www.gulbenkian. org.uk/pdffiles/-item-1266-223-No-fear-19-12-07.pdf. Accessed 20 May 2015.

Ginsburg, K. R., Committee on Communications, and Committee on Psychosocial Aspects of Child and Family Health. (2007). The importance of play in promoting healthy child development and maintaining strong parent-child bonds. American Academy of Pediatrics, 119(1), 182-191. http://pediatrics.aappublications.org/content/119/1/182. full. Accessed 20 May 2015.

Goodin, R. E., Mahmud Rice, J., Bittma, M., \& Saunders, P. (2005). The time-pressure illusion: discretionary time vs. free time. Social Indicators Research, 73, 43-70.

Griffiths, M. (2011). Favoured free-time: comparing children's activity preferences in the UK and the USA. Children and Society, 25(3), 190-201.

Grisby-Toussaint, D. S., Chi, S.-H., \& Fiese, B. H. (2011). Where they live, how they play: neighborhood greenness and outdoor physical activity among preschoolers. International Journal of Health Geographics, 10, 66. doi:10.1186/1476-072X-10-66.

Guèvremont, A., Findlay, L., \& Kohen, D. (2014). Organized extracurricular activities: are in-school and out-of-school activities associated with different outcomes for canadian youth? Journal of School Health, 84(5), 317-325.

Hood, S. (2007). Reporting on children's well-being: the state of London's children reports. Social Indicators Research, 80, 249-264.

Howard, J., \& McInnes, K. (2012). The impact of children's perception of an activity as play rather than not play on emotional well-being. Child Care Health and Development, 39(5), 737-742.

Humblet, P. (2011). Population growth in Brussels and inequality of access to kindergarten. Brussels studies, Vol. 51, pp. 1-11. http://www.brusselsstudies.be/medias/publications/BruS51EN.pdf. Accessed 20 May 2015.

Janssen, I., \& Rosu, A. (2015). Undeveloped green space and free-time physical activity in 11 to 13-year-old children. International Journal of Behavioral Nutrition and Physical Activity, 12, 26. doi:10.1186/s12966-015-0187-3.

Janssens, R. (2013). BRIO—-taalbarometer 3: diversiteit als norm. Brussel: BRIO. http://brussel.vlaanderen.be/userfiles/briotaalbarometer3.pdf. Accessed 20 May 2015.

Kaat, J., Layeux, M., Snick, A. (2011). Pratiques sociales et univers des familles monoparentales d'origines culturelles diverses en Région de Bruxelles-Capitale. Bruxelles: Flora. http://www.florainfo.be/IMG/pdf/etude_pratiques_sociales_et_univers_des_familles_monoparentales.pdf. Accessed 20 May 2015.

Kaga, Y., Bennett, J., Moss, P. (2010). Caring and learning together. A cross-national study on the integration of early childhood care and education within education. Paris: UNESCO. http://unesdoc.unesco.org/images/0018/001878/187818E.pdf. Accessed 20 May 2015.

King, P., \& Howard, J. (2012). Children's perceptions of choice in relation to their play at home, in the school playground and at the out-of-school club. Children and Society, 28(2), 116-127.

Legendre, A. (2011). Les lieux de jeux extérieurs des enfants d'âge scolaire: des espaces de proximité aux espaces publics urbains. Pratiques psychologiques, 17(1), 31-48.

Leira, A. (2002). Working parents and the welfare state. Family change and policy reform in Scandinavia. Cambridge: University Press.

Leroy, C., Van Leeuw, V., Englert, Y. (2013). Données périnatales en région bruxelloise-Année 2011. Bruxelles: Centre d'épidémiologie périnatale. http://www.cepip.be/pdf/rapport_CEPIP_BxI2013_tma-FR.pdf. Accessed 20 May 2015.

Mahatmya, D., \& Lomhan, B. (2011). Predictors of late adolescent delinquency: the protective role of after-school activities in low-income families. Children and Youth Services Review, 33(7), 1309-1317.

Mason, J. (2004). Semistructured interview. In: M. S. Lewis-Beck, A. Bryman, T. Futing Liao (Eds.), The SAGE encyclopedia of social science research methods. doi:http://dx.doi.org/10.4135/9781412950589.

Mayall, B. (2000). The sociology of childhood in relation to children's rights. The International Journal of Children's Rights, 8 , 243-259.

McHale, S., Crouter, A. C., \& Tucker, C. J. (2001). Free-time activities in middle childhood: links with adjustment in early adolescence. Child Development, 72(6), 1764-1778.

McLaughlin, E., \& Glendinning, C. (1994). Paying for care in Europe: is there a feminist approach? In L. Hantrais \& S. Mangen (Eds.), Concepts and contexts in international comparisons: family policy in the welfare of women. Centre for European Studies: Loughborough.

Millar, J., \& Warman, A. (1996). Family obligations in Europe. London: Joseph Roundtree Foundation.

Ministère de la Communauté française. (2003). Décret relatif à la coordination de l'accueil des enfants durant leur temps libre et au soutien de l'accueil extrascolaire. N-27828-July 3, 2003. Bruxelles: Parlement de la Communauté française. http://www.one.be/index.php?id=2444. Accessed 20 May 2015.

Mollo-Bouvier, S. (1994). Diversité et unité d'un temps libre très convoité: les vacances des enfants. Revue de l'Institut de sociologie, Vol. 1-2, pp. 85-102. http://cat.inist.fr/?aModele=afficheN\&cpsidt=2868028. Accessed 20 May 2015.

Morabito, C., Vandenbroeck, M., Roose, R. (2013). 'The greatest of equalisers': a critical review of international organisations'views on early childhood care and education. Journal of Social Policy. doi:10.1017/S0047279413000214.

Nippold, M. A., Duthie, J. K., \& Larsen, J. (2005). Literacy as a leisure activity: free-time preferences of older children and young adolescents. Language Speech and Hearing Services in Schools, 36, 93-102.

Observatoire de la santé et du social de Bruxelles-Capitale (OBSS). (2014). Baromètre social 2014. Rapport bruxellois sur létat de la pauvreté. Bruxelles: Commission communautaire commune. http://www.observatbru.be/documents/publications/publications-pauvrete/rapports-pauvrete.xml?lang=fr. Accessed 20 May 2015.

Oliver, M., Witten, K., Kearns, R. A., Mavoa, S., Badland, H. M., Carroll, P., et al. (2011). Kids in the city study: research design and methodology. BioMed Central Public Health, 11, 587. doi:10.1186/1471-2458-11-587. 
Programme for International Student Assessment—PISA. (2012). Country note: Belgium. Paris: OECD. http://www.oecd. org/pisa/keyfindings/pisa-2012-results.htm. Accessed 22 Feb 2014.

Rasmussen, K. (2004). Places for children—children's places. Childhood, 11(2), 155-173.

Riggio, E. (2002). Child friendly cities: good governance in the best interests of the child. Environment and Urbanization, $14(2), 45-58$.

Rorie, M., Gottfredon, D. C., Cross, A., Wilson, D., \& Connell, N. M. (2011). Structure and deviancy training in after-school programs. Journal of Adolescence, 34(1), 105-117.

Strandell, H. (2013). After-school care as investment in human capital—from policy to practices. Children and Society, 27(4), 270-281.

ULB-IGEAT, Observatoire de la Santé et du Social (OBSS). (2010). Fiches communales d'analyse des statistiques locales en Région bruxelloise. Bruxelles: Commission communautaire française. http://www.observatbru.be/documents/publications/fiches-communales-2010.xml?lang=fr. Accessed 20 May 2015.

United Nations General Assembly (Eds.). (1989). Convention on the rights of the child. New York: United Nations. http:// www.ohchr.org/en/professionalinterest/pages/crc.aspx. Accessed 20 May 2015.

Vander Gucht, D. (1995). Les investissements éducatifs des familles en Communauté française. Revue de l'institut de sociologie, 3/4. http://www.openedition.org/13379. Accessed 20 May 2015.

Vandewater, E. A., Bickham, D. S., \& Lee, J. H. (2006). Time well spent? Relating television use to children's free-time activities. Pediatrics, 117(2), e181-e191.

Veith, J., Bagley, S., Ball, K., \& Salmon, J. (2006). Where do children usually play? A qualitative study of parents' perceptions of influences on children's active free-play. Health and Place, 12(4), 383-393.

World Health Organization (WHO). (2014). Nutrition topic: Controlling the global obesity epidemic. http://www.who.int/ nutrition/topics/obesity/en/. Accessed 19 Oct 2014

Zeiher, H. (2011). Institutionalization as a Secular Trend. In J. Qvortrup, W. A. Corsaro, \& M.-S. Honig (Eds.), The Palgrave handbook of childhood studies (pp. 127-139). Basingstoke: Palgrave Macmillan.

\section{Submit your manuscript to a SpringerOpen ${ }^{\circ}$ journal and benefit from:}

- Convenient online submission

Rigorous peer review

- Immediate publication on acceptance

- Open access: articles freely available online

- High visibility within the field

- Retaining the copyright to your article

Submit your next manuscript at $\boldsymbol{s p r i n g e r o p e n . c o m ~}$ 